\title{
柔軟指先による把握物体のエッジ方向の触覚計測
}

\author{
村上 剛 司* 長谷川 勉*
}

\section{Tactile Sensing of Edge Direction of an Object using a Robotic Fingertip with Soft Skin}

Kouji Murakami* and Tsutomu Hasegawa*

\begin{abstract}
We propose a new method of tactile sensing for a fingertip of robotic hand. Using a simple fingertip with soft surface cover and a six-axis force/moment sensor, developed is a new function of measuring direction of edge when the fingertip contacts with an edge of the object. The developed function is useful not only to plan strategies for stable grasp and dexterous manipulation but also to recognize a geometrical shape of an object. Two necessary components, a six-axis force/moment sensor and the soft skin, are commercially available. They will neither restrict design of a robotic fingertip nor badly affect essential functions of stable grasping and manipulation.
\end{abstract}

Key Words: Tactile Sensing, Soft Contact, Multifingered Robotic Hand

\section{1.はじめに}

多指ハンド [1] [2] による物体の把握や操りには, 操作対象の 幾何形状や位置姿勢の認識が不可欠である。この認識を目的と して視覚センサや多数素子分布型の触覚センサを用いた研究が 報告されてきたが，解決すべき課題もいまだ多い。視覚は指自 体による把握物体の鿵蔽を避け得ないし, 照明や複雑背景も誤 認識の原因となる。一方, 多指ハンドと対象を直接接触させて 行う触覚センシングでは, 視覚のように環境条件により誤認識 することはない。しかし，多指ハンドで素子分布型の触覚センサ を用いるには，配線や費用㧍よび自由曲面形状を持つセンシン グ部位への多数の触覚素子の適切な分散配置などに課題が残っ ている，現状ではロボット指に装着して使用できる実用的な商 用センサが力覚センサに限られていることから，物体認識を行

うには多指ハンドのセンシング能力は十分ではない.

そこで我々は, 力覚センサ情報を用いたセンシング手法を開 発した。本稿では，柔軟被覆と 6 軸力覚セン开を用いて，指先 と接触する対象物体のエッジ方向 (Fig. 1) を計測する触覚セ ンシングを提案する。提案する触覚センシングは視覚のように 環境条件に起因する誤認識がなく，物体のエッジを利用した操 作や，手探りによる物体認識の実現に道を開くものである。そ の特徴を以下に示す.

（1）必要なハードウェアは柔軟被覆を持つロボット指先と 6 軸 力覚センサのみ

（2）指先力の方向を変化させるなどの探索的な能動センシング

原稿受付 2005 年 3 月 2 日

*九州大学

${ }^{*}$ Kyushu University
を行わないので, 多指ハンドの基本機能である把握と操作 の両機能を妨げない

（3）純粋に指先の感覚のみでエッジ方向を計測するため対象の 幾何形状モデルが不要

（4）ロボット指先の形状に制限はなく，その柔軟被覆は摩擦の 調節を実現するなどハンドの操作能力向上にも有効 [3]

（5）６軸力覚センサは商用センサを利用可能であり，ロボット 指の力制御にも用いられる

筆者らは, 従来の硬い指先に対して, 柔軟被覆を持つ指先を 用いることで，多指ハンドが新たな機能を獲得できることをこ れまでに示している [4]．提案する触覚センシングも，この柔軟 被覆を持つ指先を使用することで初めて可能となる。

触覚センサ情報や視覚センサ情報を用いて物体の幾何形状や 位置姿勢の認識を行った研究は, これまでにいくつか報告され ている. Fearing [5]は，ロボット指に装着した触覚センサに棒 状の小片を接触させたときに得られる触覚パターンが棈円形状 になることに注目し，楕円の長軸方向を小片の方向としてその 姿勢を求めた。下条ら [6] は, 触覚画像をビデオ信号に変換す れば画像処理の技術を適用できることを示し，物体の輪郭像を

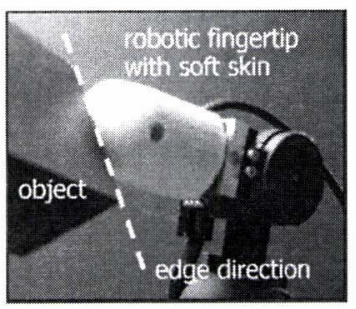

Fig. 1 Edge direction of object 
抽出している，これらの研究では，触覚素子を広範䎴かつ密に 配置して対象の全体像を取得する必要がある。しかし, 多指口 ボットハンドの表面全体に触覚素子を配置することは費用や配 線の面から難しく，実現例はほとんどない。シート状の分布型 触覚センサを装着した Gifu Hand [7] はその希有な実現例であ るが，これもセンサ自体が高価であるし，いかにしてハンドの 形状にシートをフィットさせるかということに課題が残ってい る。また，物体形状の認識に使用できたとの報告はない．

・般的には，口ボット指に実装し得る触覚の領域は対象物体 より小さい。したがって, 触覚センサからは対象物体の局所的 な情報のみが得られ，対象の全体像を一度ではセンシングでき ない。この局所性を回避するために触覚センサはアクチュエー 夕と組み合わされて使用され，能動的に対象の情報を獲得する アクティブセンシング [8] [9] が行わ机る. 石井らは, 分布型の 平面型触覚センサで触覚パターンを獲得する際の触運動の最適 化について述べている [10].

力覚や触覚から得ら机た局所情報と物体モデルとのマッチン グを行うことで, 対象の位置姿勢を求める試みもなされてい る [11]. 触覚センサを対象物体表面のどの部位と接触させたか によって，得られる触覚画像は異なる。これを整理するため， 木下ら [12] は接触のさせ方で無限に得られる触覚面像を有限個 の Haptic Aspectに分類し，その遷移関係を表現する Haptic Aspect Graph Representation を提案している.

物体の位置姿勢を計測するために，視覚情報と力触覚情報を 統合したセンサフュージョンの研究も報告されている [13] [14]. しかしこれらは，物体表面に視覚により識別可能な特徴点があ ることを前提とし，かつ特徽点のテンプレート画像を事前に用 意する必要がある。石川ら [15]は，視覚情報から得ら机る物体 の位置姿勢の精度を高めるために, 触覚センサを接触させるべ き対象物体表面位置を計画している。

また，手探りによる物体幾何形状の認識を行った研究も報告 されている. 永田らは, 多関節指の指先を対象に接触させ指先に 装着した 6 軸力覚センサの出力から求めた指先表面の接触点位 置と接触法線から物体幾何形状の認識を試みている [16]. ただ し，この手法では指先は面と接触するという仮定をおいている.

これらのほかにも，多指ハンドへの適用を机らいとした触覚 センサの開発が広く行われている[17] [18] が, 実際に多指ハン ドに触覚センサを装着した例は少なく，研究室レベルの特殊な センサの域を出ていない。また，把握が不安定になることや接 触状態の解析が困難であるなどの理由から，指先は物体のエッ ジを避けて接触させることが普通であった，提案する触覚セン シングは，すでに実用化されている商用力覚センサを用いるた め実装が容易であり，かつ物体のエッジに指先を接触させて行 う操作への道を開くものである. 本論文では, 提案する触覚七 ンシングについて以下の点を明らかにする.

(1) エッジ方向の計測原理

（2）エッジの角度，指先力の大きさ，指先の柔軟被覆の厚さお よび材質のそれぞれがエッジ方向の計測に与える影響

\section{2. 物体のエッジ方向の計測}

\section{1 柔軟指先と物体エッジとの接触}

柔軟指先による接触では対象の面とエッジで物理的な拘束が 異なるため, 指先に伝達さ机る回転摩擦モーメントの值が異な る。筆者らはこ机に着目し, 柔軟被覆と6 軸力覚センサを有す るロボット指先を用いて，操作中の物体表面の面とエッジの間 を指先が移動する際の接触状態変化を検出する手法をこれまで に提案している [4]. 本研究では, この手法を発展させて, 指先 が物体のエッジに接触した場合に，指先座標系におけるそのエッ ジ方向を計測する手法を提案する，以下，手法の原理を述べる。

まず，柔軟指先と剛体のエッジとの接触の特性を調䍒するた めに予備実験を行った。 その結果, 柔軟被覆を有する指先を用 いると, 操作の際に指先に伝達される回転摩擦モーメントの值 が，指先座標系に拀けるエッジの方向によっても変化すること が分かったししし，この現象を委軟被覆の粘弾性特性，変形 のヒステリシス，表面摩擦などのミクロな振る舞いに基づいて 完全に説明することは極めて困難である。一方，従来より巢軟 被覆を介した接触についてはソフトコンタタトの概念（Fig. 2) に基づいて, 多くの理論的研究がなされている [19]. 本研究で はソフトコンタクトモデルに基づき，指先に伝達さ机る回転摩 擦モーメントを以下のように解釈してエッジの方向の導出を試 みた。

ソフトコンタクトモデルのもとでは, 3 軸方占の力に加えて, 接触面に垂淔な軸回りの[回転摩擦モーメントを伝達できる。し たがって，対象物体の面と指先が接触している場合には，指先 に伝達さ机る回転摩擦モーメントは, 指先表面上の接触面に垂 直な軸回りのみとなる（Fig. 2(a))，次にエッジとの接触を考 える。ここで，エッジを構成する二つの面をそれぞれエッジ面 $P_{A}, P_{B}$, そ机らの面に垂直な軸を法線軸 $N_{A}, N_{B}$ と呼ぶ。 ま た，接触点位置における指先表面の法線方向を接触法線，エッ ジと接触法線に垂直な軸を接線軸と呼ぶ. 物体のエッジと指先 が接触している場合には，エッジのめり込みに伴ってエッジ面 $P_{A}, P_{B}$ と指先の柔軟被覆部が接触する (Fig. $\left.2(\mathrm{~b})\right)$. したがっ て, 法線軸 $N_{A}, N_{B}$ 回りの回転摩擦モーメントがそれぞれ指先 に伝達される。各法線軸は, 指先表面の接触法線方向と接線軸 方向の うつの方向成分で構成さ机る（Fig. 3）ため, 指先に伝 達された回転摩擦モーメントから接触法線回りの成分を消去す れば，接線軸方向回りの回転摩擦モーメントが求まる。本稿で は，この接線軸方向回りの回転摩擦モーメントを回転摩擦モー メントの接線成分と呼ぶ，回転摩擦モーメントの接線成分と接

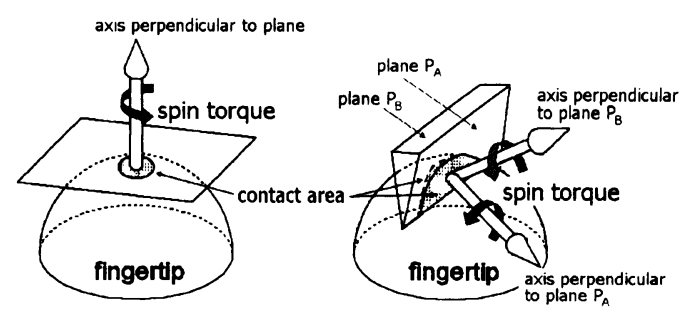

(a) Contact with plane

Fig. 2 Soft contact model 


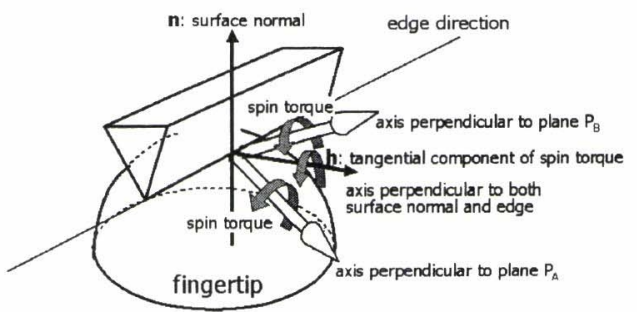

Fig. 3 Geometric relationship at contact

触法線の外積として, エッジの方向が求まる。なお，エッジの 両面で指先と接触しているが，エッジの両面の回転摩擦モーメ ントの接線成分は回転方向が同じであるので相互に打ち消され ない.

\section{2 エッジ方向の導出式}

本節では，柔軟被覆と 6 軸力覚センサを持つロボット指先で 把握した物体の，エッジ方向を計測するセンシング手法を定式 化する。ここでは, 指先の幾何形状は既知であり, かつ接触点 位置は計測可能であると仮定する。指先表面上の接触点位置を $\mathbf{r}$, 接触点で指先に加わる力とモーメントをそれぞれ $\mathbf{f}, \mathbf{m}$ とお く，力とモーメントは，指先に装着された 6 軸力覚センサの出 力から求まる. Bicchiの手法 [20] 適用すれば， 6 軸力覚セン サの出力と指先の幾何形状情報から接触点位置 $\mathrm{r}$ を求めること ができる、力とモーメントの釣り合いの式から，指先に伝達さ れている回転摩擦モーメント q が求まる.

$$
\mathrm{m}=\mathrm{q}+\mathrm{r} \times \mathrm{f}
$$

なお，指先座標系はセンサ座標系と一致しており，これらすべ てのベクトルは指先座標系で表現されているとする． $q$ から $\mathrm{r}$ での接触法線方向成分を消去したベクトル $\mathrm{h}$ は, 式 (3) で定義 できる。前節の定義より，hは回転摩擦モーメントの接線成分 を表す，接触法線ベクトル $\mathrm{n}$ とベクトル $\mathrm{h}$ との外積ベクトルと して，接触点における物体のエッジ方向が指先座標系で求まる.

$$
\begin{aligned}
& \mathbf{n}=\frac{\nabla S(\mathbf{r})}{\|\nabla S(\mathbf{r})\|} \\
& \mathbf{h} \equiv \mathbf{q}-(\mathbf{q} \cdot \mathbf{n}) \cdot \mathbf{n}
\end{aligned}
$$

ただし， $\nabla$ は微分演算子ナブラ, $S(\mathbf{r})$ は指先の幾何形状を表 す関数である。

\section{3. 柔軟指先と触覚センシングの実装}

筆者らはこれまでに，柔軟被覆と 6 軸力覚センサを持つロボッ 卜指先を開発している $[4]$. 開発した采軟指先の内部構造と外観 をFig. 4 に示す。この指先はアルミニウム製の内殼と爪，シリ コーン（硬度［アスカーC］20）製の柔軟被覆で構成されてい る。シリコーンの硬度は人間の指の柔らかさに近い.内殼を覆 う被覆部は内殸と同心の半球形状をなし, その肉厚は一定であ る.内殼には 6 軸力覚センサ（ビーエルオートテック (株) ビー エル・NANO センサ) が装着されており，指先に加わる 3 軸方 向の力と 3 軸方向回りのモーメントを計測できる.

物体の面と柔軟指先が接触している場合には, 6 軸力覚セン サの出力と指先の幾何形状から接触点位置を求めることができ

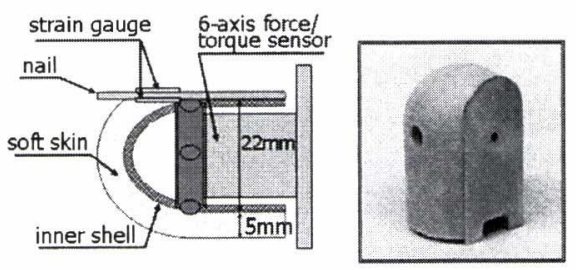

Fig. 4 Soft fingertip with nail

る。本研究では, Bicchiの手法 [20] を用いて, この接触点位置 計測を実装した。しかし，Bicchiの手法では接触点に拈いて接 触法線回りのみに回転摩擦モーメントが生じているという仮定 のもとで接触点位置を計測するため，エッジと接触する際には この仮定が成り立たず誤差が大きくなる，そこで，指へのエッ ジのめり込みが小さい間は, 接触法線回り以外の方向成分の回 転摩擦モーメントは十分小さいと仮定して, 指が対象に接触し 始めた時にBicchi の手法で接触点を求めることにした。センシ ング動作中にはこの接触点位置が動かないと仮定して，エッジ 方向の計測を行う。

提案する触覚センシングでは, 回転摩擦モーメントの接線成 分が生じて指先に伝達されている必要がある。しかし, 多指八 ンドの関節軸構成や把握時の指の姿勢およびエッジ方向の関倸 によっては, 回転摩擦モーメントの接線成分を生じさせること ができない把握形態も例外的に起こりうる。この問題を回避す

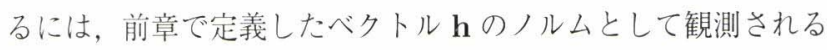
回転摩擦モーメントの接線成分を大きくするような指動作を行 う必要がある。

\section{4. 実験}

物体把握を行い, 指先と接触した物体エッジの方向を計測す 万. 実験装置を Fig. 5 に示す. 2 本の 4 関節指 (安川電機製) が対向して手掌部に配置されており，各指の先端には開発した 柔軟指先が装着されている。対象物体は直方体の端にエッジ部 を接着して使用した。このエッジ部は異なる角度のものに適宜 交換することができる。また，ハンド座標系はハンドの手掌部 中心に固定されている。

実験手順を以下に示す.

（1）対向 2 指を初期姿勢から互いに近付けていく.

（2）指先が把握対象物体に接触したら指先表面の接触点位置を 求める.

（3）各指は二つの接触点を結ぶ方向へ指先力を加え, 物体を把 握する。

このような一般的な把握動作がセンシング動作を兼ね得る点に 注目されたい. なお， Bicchiの手法による接触点位置の計測を 精度よく行うためには，一定值以上の大きさの力が指先に加わっ ている必要がある. 永田らは $0.2[\mathrm{kgf}]$ 以上の力が加わっていれ ば, $0.5[\mathrm{~mm}]$ 以内の䛊差で接触点位置を計測できることを報告 している [21]. 本実験で使用した指先でも $0.2[\mathrm{kgf}]$ 以上の力が 加わっていれば, $0.5[\mathrm{~mm}]$ 以内の䛊差で接触点位置を計測でき ることを調査済みである [4]. そこで, 接触点位置の計測は指先 カの大きさが $0.2[\mathrm{kgf}]$ を超えた時点で行った. 柔軟被覆へのエッ 


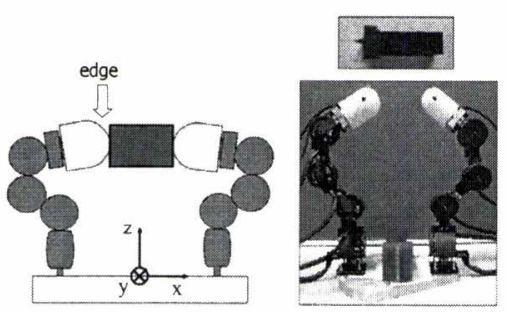

Fig. 5 Experimental setup
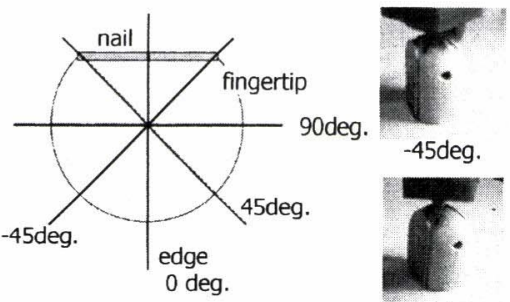

45deg.

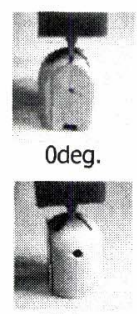

90deg.
Fig. 6 Direction of the edge

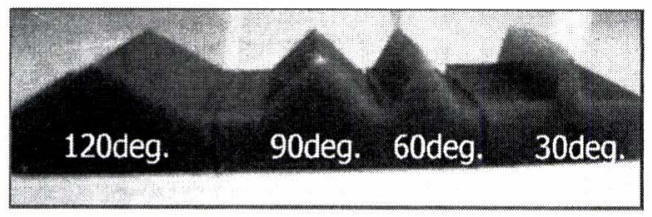

Fig. 7 Angle of edge

ジのめり込みを考慮して, 把握動作完了時の指先力の大きさは $0.5[\mathrm{kgf}]$ とした。また，指の制御周期および触覚センシングの 周期は $20[\mathrm{~ms}]$ である.

実験では，物体のエッジを 4 通りの方向で Fig. 5 の左指の指 先に接触させた，指先座標系におけるエッジの方向は，それぞ れ -45 度，0 度，45 度，90 度である(Fig. 6).

な拉，本章のすべての実験で同じ把握動作を 2 本の指に行わ せた．特にことわらない限り, 指の初期姿勢や, 把握時の関節 角度経路，指先力の大きさは同じである。また，以後のすべて の実験結果は Fig. 5 の左の指先に関するものである.

\section{1 エッジとの接触}

まず，開き角度が 60 度（Fig. 7 ) のエッジを指先と接触させ て実験を行った。な扮本稿では，開き角度とはエッジを構成す る 2 面がなす角度とする。実験結果を Fig. 8 11 に示す。そ れぞれ指先座標系に扔いて $-45 ， 0 ， 45 ， 90$ 度の方向 (Fig. 6) でエッジを指先に接触させた場合を示している。各図は左の二 つが上から 6 軸力覚センサの出力である力とモーメントであり， 右の二つが上から回転摩擦モーメントの接線成分の大きさと計 測したエッジの方である. 力とモーメントの值はハンド座標 系で，エッジ方向の值は指先座標系でそれぞれ表されている。各 図の横軸は時間を表している。実験では 0 秒から把握動作を開 始し， 2 秒近辺で指先が対象に接触し始めて，4 秒過ざに把握 動作が完了している.

エッジの方向を -45 度, 0 度, 45 度で指先と接触させた場合 はエッジの方向をよく計測できている。一方，エッジの方向を 90 度で接触させた場合は, 他の 3 方向と比べてエッジ方向の計
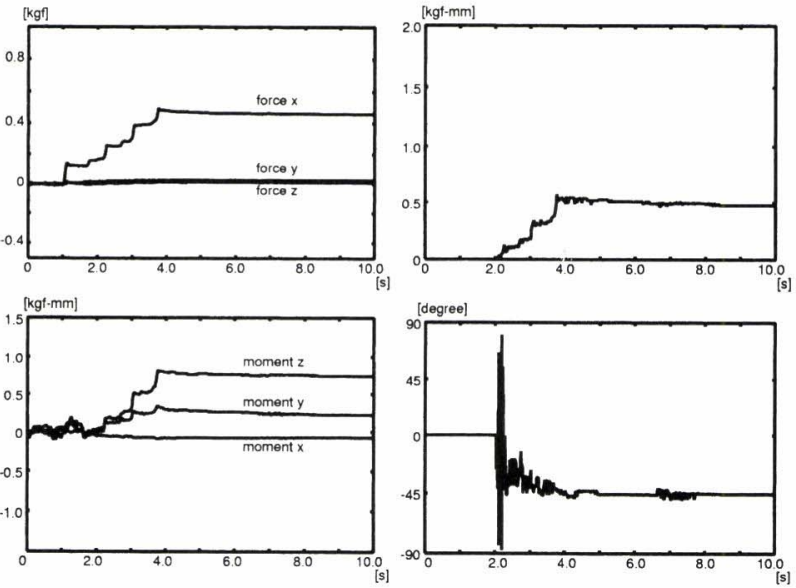

Fig. 8 Contact with the edge whose direction is -45 [degree] (upper left: force, upper right: tangential component of spin torque, lower left: moment, lower right: edge direction)
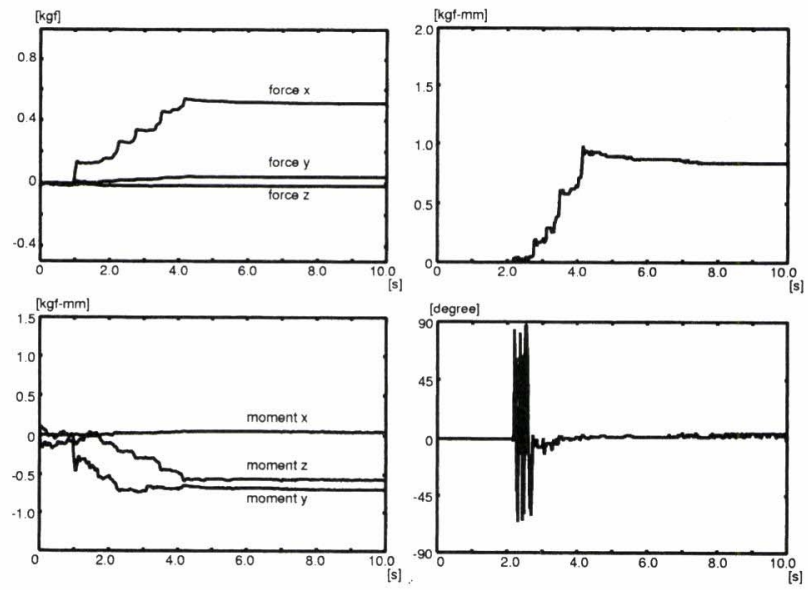

Fig. 9 Contact with the edge whose direction is 0 [degree] (upper left: force, upper right: tangential component of spin torque, lower left: moment, lower right: edge direction)

測精度が低下している。この結果は次のように説明できる。今 回の実験条件（Fig. 5）では, 把握の際には各指の上から三つの 関節が働く。この三つの関節回転軸はハンド座標系に抢ける $\mathrm{y}$ 軸と平行である。また，重力は $-\mathrm{z}$ 方向に働く，指先にエッジ 方向を 90 度で接触させた場合には, エッジの方向はハンド座 標系の $\mathrm{y}$ 軸と平行となる。このとき，エッジ方向を計測するた めには八ンド座標系の $\mathrm{z}$ 軸回りの回転摩擦モーメントが生じな ければならない。しかし, 今回の実験で行った把握動作では関 節軸構成の関係から, z 軸回りに回転摩擦モーメントを生じさ せる指先力を指関節は出力しない。寒験では, 指先の位置ずれ などの効果もあって, 90 度の場合でも回転摩擦モーメントの接 線成分の大きさは 0 とはならず小さな值か観測されている。し かし，エッジ方向の計測に十分な大きさではない。

また，エッジ方向を 30 度刻みにして同様の実験を行った結果 をFig. 12 に示す。 - 60 度から 60 度までの範囲で, エッジ方 向を安定に計測できていることが分かる.

実験結果は, 指の関節軸配置と指先力の方向に依存する計測 

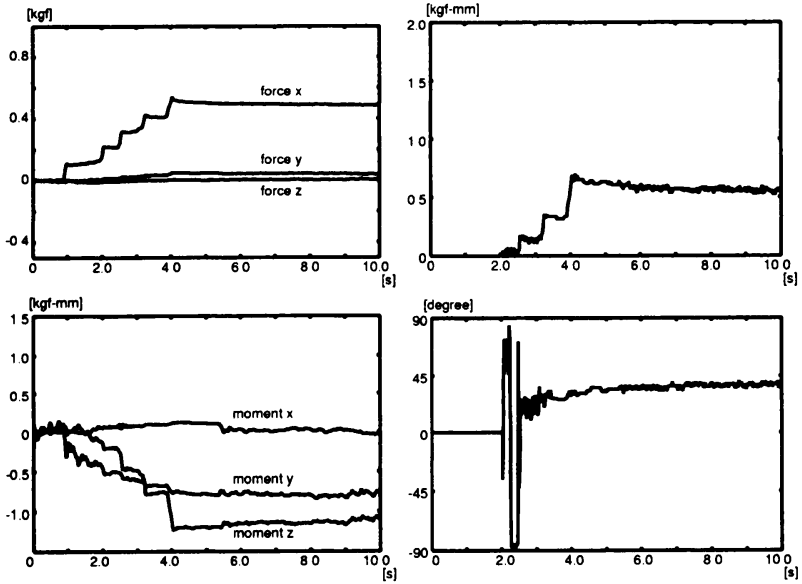

Fig. 10 Contact with the edge whose direction is 45 [degree] (upper left: force, upper right: tangential component of spin torque, lower left: moment, lower right: edge direction)
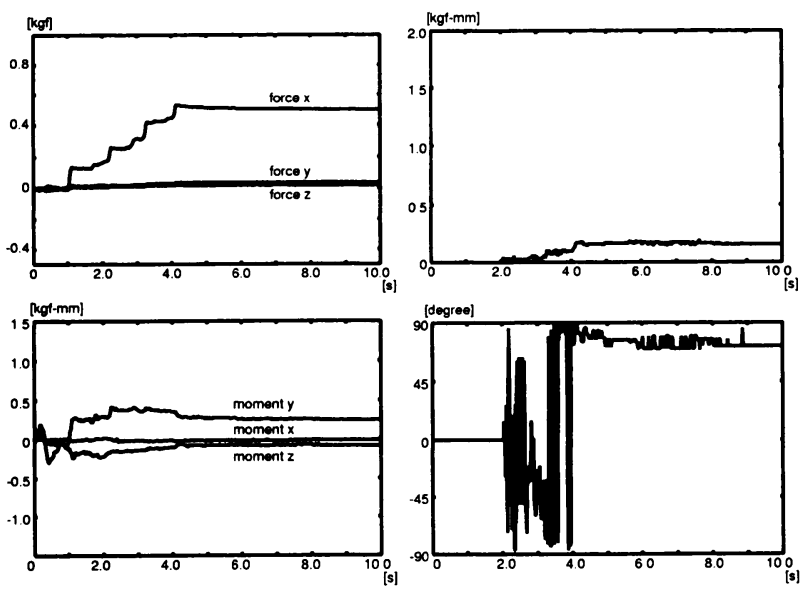

Fig. 11 Contact with the edge whose direction is 90 [degree] (upper left: force, upper right: tangential component of spin torque, lower left: moment, lower right: edge direction)

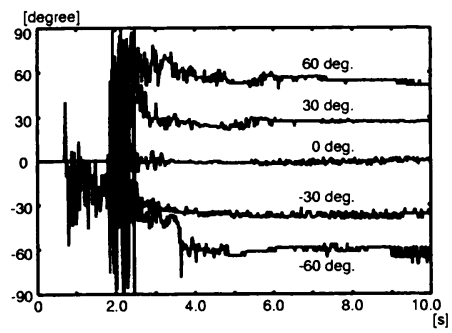

Fig. 12 Measured edge direction

可能範囲を提案手法が持つことを示している。また同時に，今 回の実験条件では最高 2 回の把握動作を指先力の方向が直交す るようにして行えば確実にエッジ方向を計測できることも分かっ た．指先力の方向を変更して回転摩擦モーメントの接線成分を 十分大きくした後にエッジ方向を求めればよい.

4.2 エッジの開き角度のちがい

エッジの開き角度を $30,60 ， 90,120$ 度（Fig. 7）と変えて
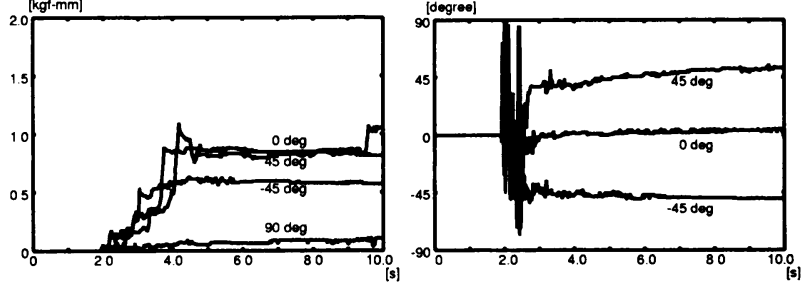

Fig. 13 Measured direction of the edge whose angle is 30 [degree] (left: tangential component of spin torque, right: edge direction
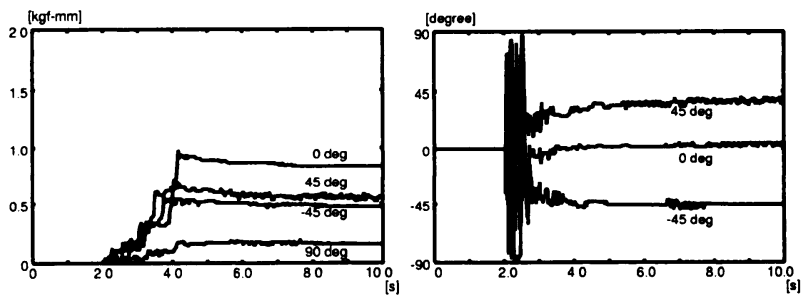

Fig. 14 Measured direction of the edge whose angle is 60 [degree] (left: tangential component of spin torque, right: edge direction)
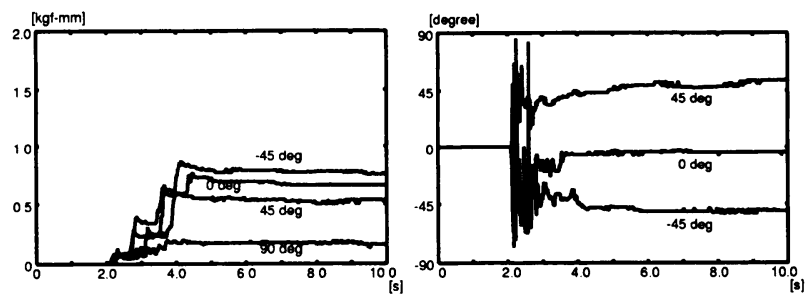

Fig. 15 Measured direction of the edge whose angle is 90 [degree] (left: tangential component of spin torque, right: edge direction)
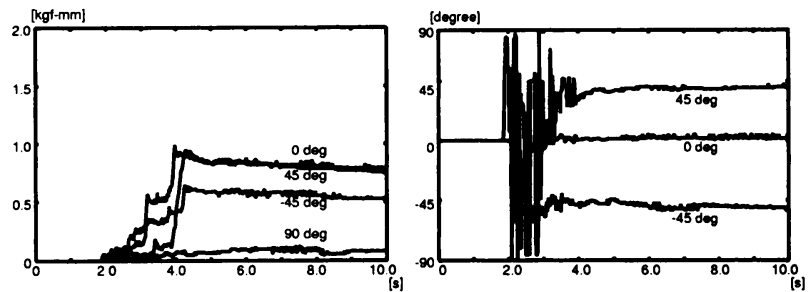

Fig. 16 Measured direction of the edge whose angle is 120 [degree] (left: tangential component of spin torque, right: edge direction)

前節と同じ実験を行った．実験結果を Fig. 13～16に示す．各 罒は，左から回転摩擦モーメントの接線成分の大きさと計測し たエッジの方向を示して抢り，横軸は時間を表している。

実験結果から，エッジの開き角度はエッジ方向の計測精度に ほとんど影響を与えないことが分かった。したがって，エッジ の開き角度にかかわらず提案手法は適用できる.

今回の実験条件では回転摩擦モーメントの接線成分の大きさ が 0.4 [kgf-mm] より小さいとエッジ方向の計測精度が低下する とともに，計測值が収束せずに乱れることが多かった。エッジ 方向を指先に対して 90 度にして接触させた場合には，この值 


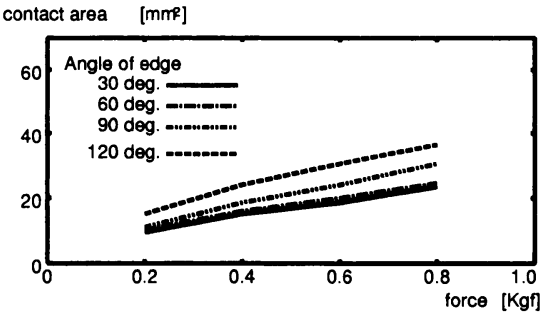

Fig. 17 Contact area
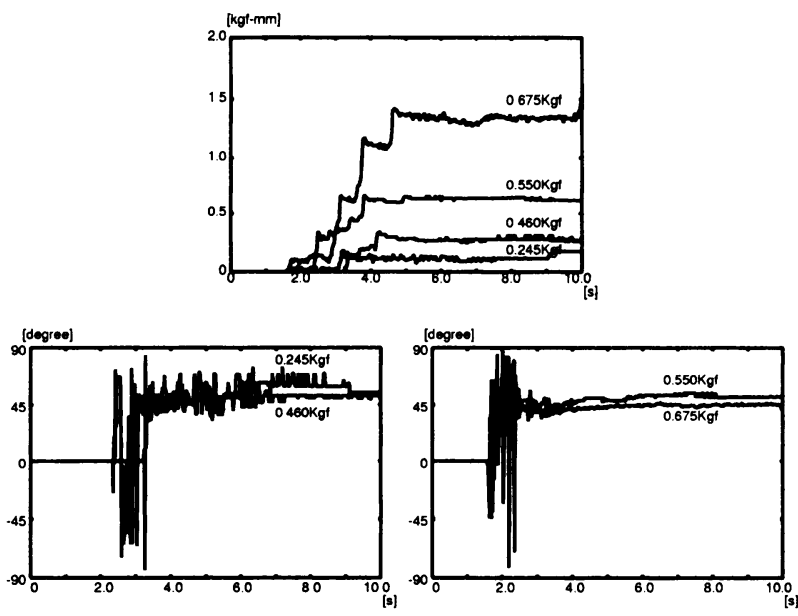

Fig. 18 Measured direction of the edge with different magnitude of grasping force (top: tangential component of spin torque, lower left and right: edge direction)

より回転摩擦モーメントが小さくなっており, エッジ方向の計 測值は乱れていた，図が見にくくなるのを防ぐため，これらの 計測值は Fig. 13〜16 から除外した.

なお，実験で使用した指先（被覆厚さ：5[mm]）は物体のエッ ジと接触する際にエッジの側面との間に接触面積を生じること を確認している，指先力の変化に対する，エッジを構成する二 つの面と柔軟被覆の接触面積変化を Fig. 17 に示す。罒の横軸 は指先力の大きさを表す．塗料を指先に塗布し，エッジとの接 触時にエッジに付着した塗料の領域から接触面積を計測した.

\section{3 指先力の大きさのちがい}

前節までの実験結果から, 今回の実験条件では指先に接触 させたときのエッジの方向が一定の範囲内であれば，設定した $0.5[\mathrm{kgf}]$ 程度の指先力の大きさで, エッジ方向をよく測定でき ることが分かった。ここで，指先力に対するエッジ方向の計測 精度と回転摩擦モーメントの接線成分の大きさとの関係を調査 するため, 指先力の大きさのみを変化させて同様の実験を行っ た。把握物体のエッジの開き角度は 90 度であり，エッジの方向 は指先に対して 45 度で接触させた。実験結果を Fig. 18 に示 す。上の図が回転摩擦モーメントの接線成分の大きさを，下の 二つの図がエッジ方向をそれぞれ表している，各図の横軸は時 間を表す. 図から, 指先力の大きさが約 0.55 [kgf] より大きけ れば, エッジ方向の計測值が早く収束し, かつ乱れも小さいこ とが分かる。

ただしこのの $0.55[\mathrm{kgf}]$ や前節で得た $0.4[\mathrm{kgf}-\mathrm{mm}]$ という值 は今回の実験条件（指先形状, 指の関節構造, 指本数, 手掌部
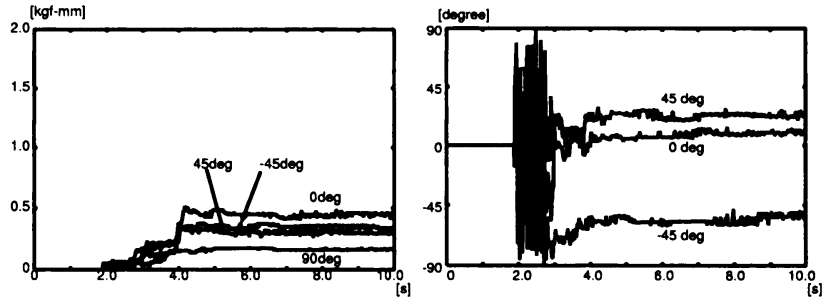

Fig. 19 Measured direction of the edge using soft skin of $3[\mathrm{~mm}]$ thickness (left: tangential component of spin torque, right: edge direction)
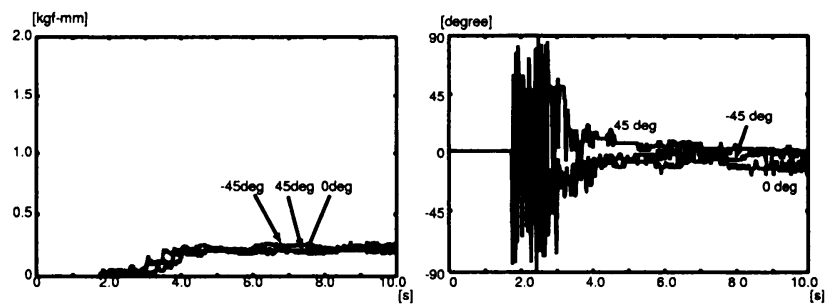

Fig. 20 Measured direction of the edge using soft skin of 1 [mm] thickness (left: tangential component of spin torque, right: edge direction)

への指配置, センシング時の指動作）のもとで経験的に得られ た值であり，実験条件に左右される值であると思われる。

\section{4 指先の柔軟被覆の厚さのちがい}

指先の柔軟被覆の厚さを $5[\mathrm{~mm}]$ から $3[\mathrm{~mm}]$ と $1[\mathrm{~mm}]$ にそ れぞれ変更して実験を行った。指先柔軟被覆の柔らかさや形状 はこ机までの実験で使用した被覆厚さ $5[\mathrm{~mm}]$ の指先と同じで ある．実験では開き角度が 90 度のエッジを使用した。実験結果 をFig. 19, 20 に示す. 各図は, 左から回転摩擦モーメントの 接線成分の大きさと計測したエッジの方向を示しており，横軸 は時間を表している。 なお，対応する被覆厚さ $5[\mathrm{~mm}]$ の結果 は，前節の Fig. 15•である。

実験では, 被覆厚さ $1[\mathrm{~mm}]$ の場合にはエッジ方向を正しく計 測できなかった。被覆厚さ $3[\mathrm{~mm}]$ の場合も被覆厚さが $5[\mathrm{~mm}]$ の場合と比べてエッジ方向の計測精度が大きく低下している. また, 被覆厚さが $1[\mathrm{~mm}]$ と $3[\mathrm{~mm}]$ の場合は回転摩擦モーメン トの接線成分の大きさが, 被覆厚さ $5[\mathrm{~mm}]$ の場合と比べて小 さくなっていた，以上より，提案手法によるエッジ方向の計測 にはある程度の被覆厚さが必要であることが分かった。これは， 従来の硬い指先に対して, 柔軟被覆を持つ指先を用いることに より初めてエッジ方向の計測が行えることを示している。ただ し, 被覆を厚くしすぎると指先表面の接触点位置の検出精度が 低下し，結果的にエッジ方向の計測精度も低下することが予想 される。

\section{5 柔軟被覆の材質のちがい}

指先の柔軟被覆の材質を変更して実験を行った．指先の被覆厚 さ $(5[\mathrm{~mm}])$ や形状は変更していない. 使用した指先の外観を Fig. 21 に示す。被覆の材質は左から, ウレタン 1（硬度 [JIS A] 30), シリコーン (硬度 [アスカーC] 20), ウレタン 2 (硬度 [アスカーC ] 15）である. 各指先の柔らかさを平面に指先を押 しつけたときの接触面積の変化で評価した．実験結果を Fig. 22 
に示す，図の横軸は指先力の大きさを表す，実験では塗料を指 先に塗布し，接触時に平面に付着した塗料の領域から接触面積 を計測した。

新しく追加した 2 種類のウレタン製指先によるエッジ方向の 計測結果を Fig. 23，24 に示す。各図は，左から回転摩擦モ一 メントの接線成分の大きさと計測したエッジの方向を示してお り，横軸は時間を表している。

実験結果から，柔らかいウレタン 2 を用いた指先の場合は他 の材料に比べてエッジ方向の計測值の安定性が悪くなっていた. また，実験結果は割爱したがウレタン 1 を用いた指先の場合は， 指先力を小さくすると計測精度が大きく低下するという結果が 得られた。これは，被覆部が硬いので指先力が小さいとエッジ の指先へのめり込みが十分ではなくなるためであると思われる. さらに，ウレタン 1 の場合は，爪を外してエッジ方向の計測を

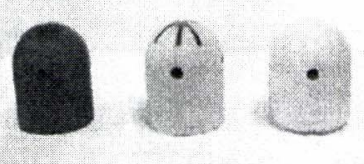

Fig. 21 Appearance of fingertips

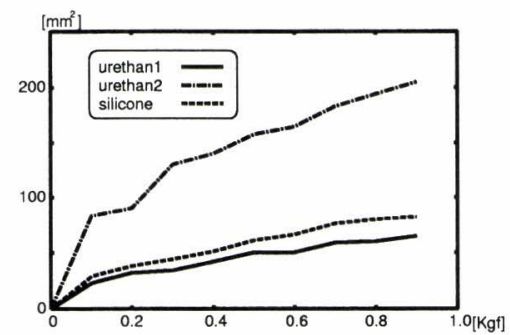

Fig. 22 Contact area between the fingertip and a plane
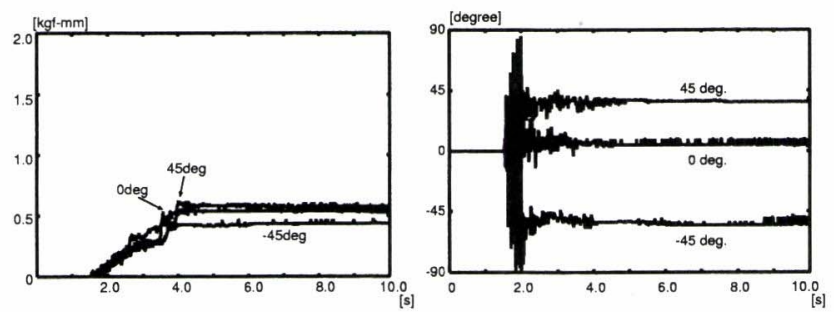

Fig. 23 Measured direction of the edge using soft skin of urethane1 (left: tangential component of spin torque, right: edge direction)
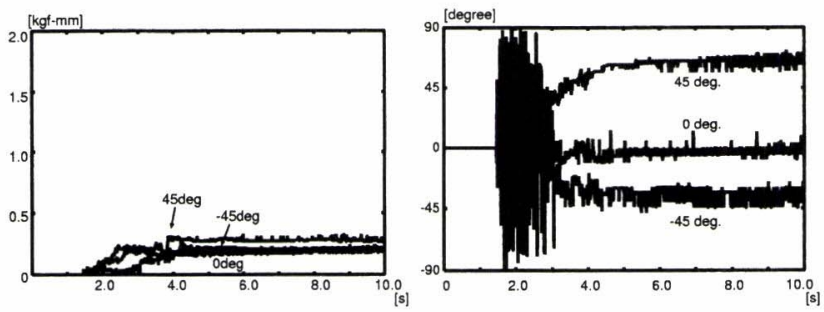

Fig. 24 Measured direction of the edge using soft skin of urethane2 (left: tangential component of spin torque, right: edge direction)
行うと計測精度が低下した。エッジが押しつけられた際の柔軟 被覆部の変形を押さえ込む効果が爪にはあるため, 爪の有無が エッジのめり込みに影響したためだと思われる。

\subsection{6 軸アームに装着した 2 本指ハンドによる把握物体の} 姿勢計測

最後に,より実際的な条件のもとで実験を行った。これまで 使用した 4 関節 2 本指ハンドを 6 軸アーム (三菱電機（株） RVE2）の先端に装着して，物体の姿勢計測を行った。実験装置を Fig. 25 に示军。対象物体は，一辺が $4[\mathrm{~cm}]$ の立方体に円錐が 接着されたものであり，その質量は $60[\mathrm{~g}]$ である。この物体を， Fig. 26〜28 に示した 3 通りの異なる姿勢で把握し，その姿勢

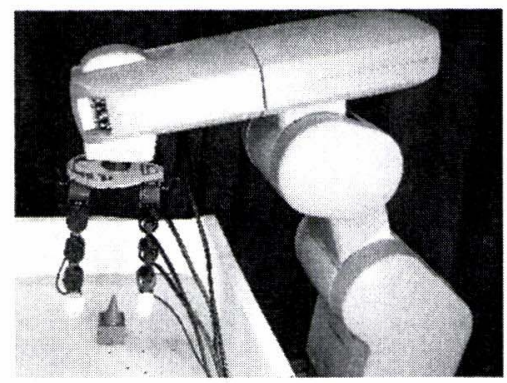

Fig. 25 Two-fingered hand mounted on 6DOF manipulator

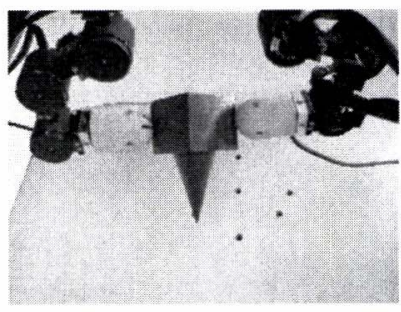

[front view]

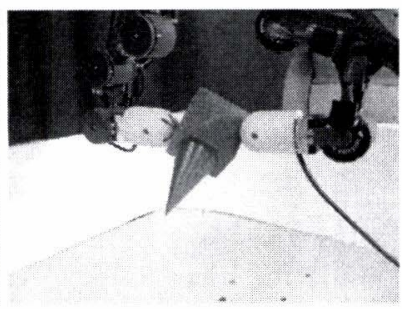

[side view]
Fig. 26 Grasp with the edge whose direction is -45 [degree]

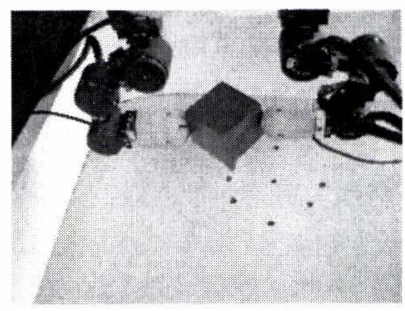

[front view]

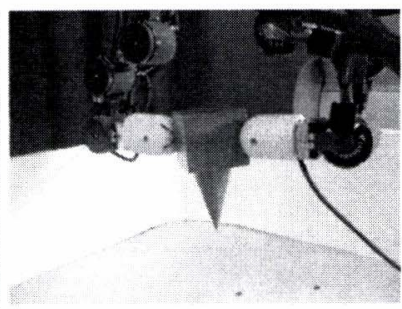

[side view]
Fig. 27 Grasp with the edge whose direction is 0 [degree]

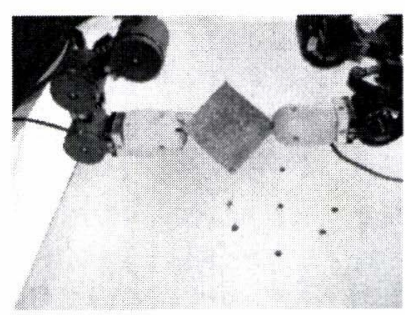

[front view]

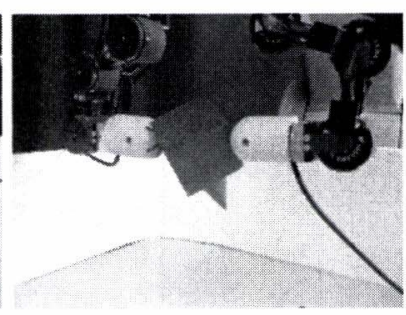

[side view]
Fig. 28 Grasp with the edge whose direction is 45 [degree] 


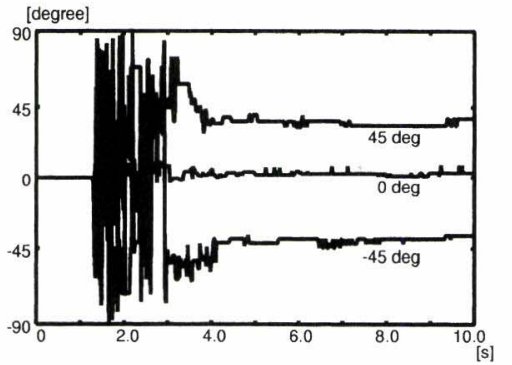

Fig. 29 Direction of the edge of the grasped object

を計測した。これらの姿勢はそれぞれ，指先に対して -45 度， 0 度，45 度で接触させた場合に対応している（Fig. 6)。実験結 果をFig. 29 に示す，異なる三つの姿勢を区別できている。

な扔，重力によって物体に生じるモーメントがエッジ計測に 与える影響はない。実際に，重力方向に関しハンドの姿勢を変 えて把握を行った実験に拀いて, 指先とエッジの相対関倸が同 じであれば計測されたエッジ方向には差がなかった。

\section{5.むすび}

ロボット指先と接触している物体のエッジ方向を計測する触 覚センシングを提案した，柔軟被覆と 6 軸力覚センサを持つロ ボット指先を装着した 4 関節 2 本指ハンドを用いて実験を行い, 提案する触覚センシングが単純な把握動作で実現できることと, エッジの開き角度にかかわらず適用できることを確認した。さ らに指先力の大きさや，指先の柔軟被覆の厚さと材質がエッジ 方向の計測精度に与える影響について調査した。

提案手法は指先がエッジと接触している際に回転摩擦モーメ ントの接線成分が十分に生じていないと，原理的にエッジ方向 の計測精度が低下する. 実験結果からもこの傾向は明らかであっ た。回転摩擦モーメントの接線成分を適切に発生させるための 指動作の検討が今後の課題である。また, 指先の形状がエッジ 方向の計測精度に与える影響の調査や, エッジ方向の計測に適 した柔軟被覆厚みの決定と材質の選定も必要である。

\section{参 考 文 献}

[1] 金子真：“多指ハンド”, 日本ロボット学会誌, vol.16, no.7, pp.889 892, 1998.

[2] A. Bicchi: "Hands for Dexterous Manipulation and Robust Grasping: A Difficult Road Toward Simplicity," IEEE Trans. RA, vol.16, no.6, pp.652-662, Dec. 2000.
[3 ] K. Murakami and T. Hasegawa: "Novel Fingertip Equipped with Soft Skin and Hard Nail," Proc. IEEE ICRA, pp.708-713, 2003.

[4] 村上剛司, 長谷川勉：“器用な多関節多指ロボットハンドのための柔軟 被覆と爪を有する指先”, 日本ロボット学会誌, vol.22, no.5, pp.616624, 2004.

[5 ] R.S. Fearing: "Some Experiments with Tactile Sensing during Grasping," Proc. IEEE ICRA, pp.1637-1643, 1987.

[6] M. Shimojo, M. Ishikawa and K. Kanaya: "A Flexible High Resolution Tactile Imager with Video Signal Output," Proc. IEEE ICRA, pp.384-391, 1991.

[7] H. Kawasaki, T. Komatsu and K. Uchiyama: "Dextrous Anthropomorphic Robot Hand with Distributed Tactile Sensor: Gifu Hand II," IEEE/ASME Trans. on Mechatronics, vol.7, no.3, Sep. 2002.

[8] H. Maekawa, K. Tanie, K. Komoriya and M. Kaneko: "Development of a Finger-Shaped Tactile Sensor and its Evaluation by Active Touch," Proc. IEEE ICRA, pp.1327-1334, 1992.

[9] 石川正俊：“アクティブセンシングとロボットハンド”, 日本ロボット 学会誌, vol.11, no.7, pp.938-942, 1993.

[10] 石井抱, 石川正俊：“分布型触覚センサを用いた触覚パターン獲得のた めの能動的触連動”, 日本ロボット学会誌, vol.15, no.5, pp.795-801, 1997.

[11] 永田和之：“把握中のセンシング戦略 その 2 : 把持物体の把握位置 姿勢推定”, 日本ロボット学会誌, vol.11, no.7, pp.973-979, 1993.

[12] G. Kinoshita, E. Mutoh and K. Tanie: "Haptic Aspect Graph Representation of 3-D Solid Object Shapes by Tactile Sensing," Proc. IEEE/RSJ IROS, pp.1912-1917, 1992.

[13] K. Honda, T. Hasegawa, T. Kiriki and T. Matsuoka: "RealTime Pose Estimation of an Object Manipulated by a MultiFingered Hand Using 3-D Stereo Vision and Tactile Sensing," Proc. IEEE/RSJ IROS, pp.1814-1819, 1998.

[14] 横小路泰義, 坂本守行, 吉川恒夫：“カメラ画像を併用した多指ハンド により操ら机る物体の位置姿勢推定法”, 日本ロボット学会誌, vol.18, no.3, pp.401-410, 2000.

[15] 向井利春, 石川正俊：“アクティブセンシングを用いた視触覚融合シ ステム”, 日本ロボット学会誌, vol.15, no.1, pp.75-81, 1997.

[16] 永田和之, 慶野知治, 小俣透：“多指ハンドの物体操作による把持 物体形状モデルの獲得”, 計測自動制御学会論文集, vol.34, no.10, pp.1487-1493, 1998.

[17] 山田陽滋：“触覚”, 日本ロボット学会誌, vol.16, no.7, pp.893-896, 1998.

[18] 篠田裕之: “接触センシングの現状と今後の展開”, 日本ロボット学会 誌, vol.20, no.4, pp.385-388, 2002.

[19] Y. Li and I. Kao: "A Review of Modeling of Soft-Contact fingers and Stiffness Control for Dexterous Manipulation in Robotics," Proc. ICRA, pp.3055-3060, 2001.

[20] A. Bicchi: "Intrinsic Contact Sensing for Soft fingers," Proc. of IEEE ICRA, pp.968-973, 1990.

[21] 永田和之, 津村稔, 小俣透: “指先力覚センサの開発と接触点検出䛊 差評価”, 日本ロボット学会誌, vol.14, no.8, pp.1221-1228, 1996.

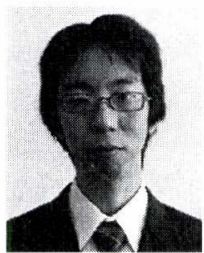

村上剛司 (Kouji Murakami)

1975 年 4 月 25 日生. 2004 年九州大学大学院シス テム情報科学府知能システム学専攻博上課程修了. 同年より九州大学大学院システム情報科学研究院助 手, 現在に至る。多関節多指ハンド, 触覚センシン グの研究に従事. 博士 (工学).

(日本ロボット学会正会員)

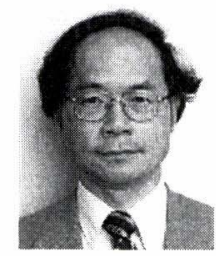

長谷川魅（Tsutomu Hasegawa）

1950 年 2 月 18 日生. 1973 年東京工業大学電子物 理工学科卒業. 同年電子技術総合研究所勤務. 1992 年より九州大学工学部情報工学科教授. 現在同大学 大学院システム情報科学研究院教授. 知能ロボッ卜 の研究に従事. 工学博士. 計測自動制御学会, 電気 学会, 日本機械学会などの会員.

(日本ロボット学会正会員) 